\title{
Altering Plant Defenses: Herbivore-Associated Molecular Patterns and Effector Arsenal of Chewing Herbivores
}

\author{
Saumik Basu, ${ }^{1}$ Suresh Varsani, ${ }^{1}$ and Joe Louis ${ }^{1,2, \dagger}$ \\ ${ }^{1}$ Department of Entomology; and ${ }^{2}$ Department of Biochemistry, University of Nebraska-Lincoln, Lincoln, NE 68583, U.S.A.
}

Accepted 23 August 2017.

Chewing herbivores, such as caterpillars and beetles, while feeding on the host plant, cause extensive tissue damage and release a wide array of cues to alter plant defenses. Consequently, the cues can have both beneficial and detrimental impacts on the chewing herbivores. Herbivore-associated molecular patterns (HAMPs) are molecules produced by herbivorous insects that aid them to elicit plant defenses leading to impairment of insect growth, while effectors suppress plant defenses and contribute to increased susceptibility to subsequent feeding by chewing herbivores. Besides secretions that originate from glands (e.g., saliva) and fore- and midgut regions (e.g., oral secretions) of chewing herbivores, recent studies have shown that insect frass and herbivore-associated endosymbionts also play a critical role in modulating plant defenses. In this review, we provide an update on a growing body of literature that discusses the chewing insect HAMPs and effectors and the mechanisms by which they modulate host defenses. Novel "omic" approaches and availability of new tools will help researchers to move forward this discipline by identifying and characterizing novel insect HAMPs and effectors and how these herbivore-associated cues are perceived by host plant receptors.

Plants deploy a diverse array of defensive strategies to overcome stress caused by insect attack. Simultaneously, insects produce a suite of herbivore-associated molecular patterns (HAMPs), analogous to pathogen-associated molecular patterns or microbeassociated molecular patterns in pathogens or microbes (Felton and Tumlinson 2008; Felton et al. 2014; Mithöfer and Boland 2008), and effectors to manipulate the plant defenses. The term "effectors" has been described as molecules secreted by pathogens and microbes that either elicit or suppress plant defenses (Asai and Shirasu 2015; Hewezi 2015; Lo Presti et al. 2015). However, in the context of this review, we define insect molecules that induce plant defenses as HAMPs or elicitors whereas those that suppress plant defenses and promote host susceptibility as effectors. These HAMPs and effectors could arise from insect oral secretions (OS) (regurgitant), saliva, ventral eversible gland (VEG) secretions, digestive waste products (e.g., frass), ovipositional fluids, and herbivore-associated endosymbionts. In addition, upon insect feeding, plants produce various endogenous wound signals (e.g., peptides) to activate the downstream defense responses (Heil et al. 2012; Huffaker et al. 2013).

${ }^{\dagger}$ Corresponding author: Joe Louis; E-mail: joelouis@unl.edu

(c) 2018 The American Phytopathological Society
Upon recognition of these multiple insect-derived cues, plants orchestrate appropriate defenses against attacking insect pests, although some of these defense responses are specific to a particular feeding guild of insect pests (Bonaventure 2012; Erb et al. 2012; Howe and Jander 2008). Several studies have shown that the insect feeding interferes with the plant stress hormones, secondary metabolism, defense proteins, resource reallocation, leaf senescence, and modulations in photosystem II to suppress or activate the plant defenses (Halitschke et al. 2011; Korpita et al. 2014; Louis et al. 2013b; Robert et al. 2014). For example, maize utilizes jasmonic acid (JA) and downstream genes that encode defense proteins to mount appropriate defenses against feeding by chewing insects (Chuang et al. 2014). Further, feeding by chewing insects results in the activation of the salicylic acid (SA) pathway, which, in turn, suppresses the JA related defenses, rendering the plants susceptible to subsequent herbivory by chewing insects (Chung et al. 2013). The crosstalk between SA and JA pathways (Koornneef and Pieterse 2008; Thaler et al. 2012) are highly induced by the effectors present in the insect secretions for their own benefit. However, a few studies have concluded that plant defense to chewing herbivores are also mediated through both JA- and SA-independent defense pathways (Consales et al. 2012; Hettenhausen et al. 2013). In this review, we will discuss the recent progress made in the field of chewing insect HAMPs and effectors and how they are involved in modulating plant defenses. We will focus our discussion on chewing herbivores and direct readers to other recent reviews that focus on piercing/sucking insects (e.g., aphids) (Kaloshian and Walling 2016; Rao et al. 2016; van Bel and Will 2016).

\section{HAMPS AND EFFECTORS OF CHEWING HERBIVORES}

OS or regurgitant.

The OS or regurgitant refers to the secretions that originate from the caterpillar mid- and foregut (Peiffer and Felton 2009). These secretions are released through the oral cavity situated between the caterpillar mandibles. Several HAMPs identified in the OS include, volicitin (fatty acid-amino acid conjugates [FACs]), caeliferins (sulfated fatty acids), and inceptins (plantderived peptide fragments) (Alborn et al. 1997, 2007; Schmelz et al. 2007). Some of these HAMPs present in the insect OS are well-studied (e.g., FACs), and studies conducted by several groups have indicated that these HAMPs can activate mitogenactivated protein kinases (MPK) and accumulation of various secondary metabolites and defense proteins and cause changes in phytohormone-signaling pathways that impact insect physiology, leading to impairment of larval growth (Halitschke et al. 2003; Hermsmeier et al. 2001; Kahl et al. 2000; Schäfer et al. 2015; Wu et al. 2007; Zavala et al. 2004) (Table 1). The 
interplay among HAMPs, activation of indirect defenses by augmenting the plant volatile profiles, and strategies by which host plants recruit predators or parasitoids of the attacking herbivore are well-documented (Alborn et al. 1997, 2003, 2007; Kessler and Baldwin 2001; Turlings et al. 1990, 1993). HAMPs could also modulate defenses by rapidly accumulating various oxylipins, such as 12-oxo-phytodienoic acid (OPDA), the precursor of JA and JA-isoleucine (Meza-Canales et al. 2017; Schäfer et al. 2011). OPDA is reported to function as a woundinduced signaling molecule in plants and activate defense responses against several insects (Bosch et al. 2014a and b; Guo et al. 2014; López-Galiano et al. 2017; Park et al. 2013; Stintzi et al. 2001; Taki et al. 2005). The OS from insects that are deposited on the plant surface also activate many of the early signaling events. For instance, OS of Spodoptera littoralis induced a rapid change in the transmembrane potential $\left(\mathrm{V}_{\mathrm{m}}\right)$ that triggers the proper activation of signaling cascades in host plants against insect attack (Guo et al. 2013). Similarly, feeding by Schistocerca gregaria, a generalist grasshopper herbivore, swiftly increased cytosolic calcium levels, MPK3 and MPK6 activity, and ethylene (ET) emission (Schäfer et al. 2011). Interestingly, it was not the caeliferins present in grasshopper OS that activated the defense response, but the lipase activity induced the rapid activation of defense responses in host plants, suggesting that multiple HAMPs present in the insect OS act synergistically or independently to modulate various defense responses in host plants.

Recently, a phospholipase $\mathrm{C}$ was also identified, in the secretions of Spodoptera frugiperda (fall armyworm [FAW]), that can modulate defense responses in various host plants (Acevedo et al. 2017a). The OS of a polyphagous caterpillar, Ostrinia nubilalis (Hübner) (European corn borer [ECB]), contained elevated levels of plant growth hormones such as auxin (Dafoe et al. 2013). In this case, ECB might be using the OS-derived auxin to enhance the nutritional quality and impact subsequent

Table 1. Herbivore-associated molecular patterns and effectors identified in various chewing herbivores and its effect on different host plants ${ }^{\mathrm{a}}$

\begin{tabular}{|c|c|c|c|c|c|}
\hline Insect & Source & Component & Host & Response & Reference \\
\hline \multirow[t]{2}{*}{$\begin{array}{l}\text { Helicoverpa armigera (cotton } \\
\text { bollworm) }\end{array}$} & Saliva & GOX & $\begin{array}{r}\text { Nicotiana } \\
\text { tabacum }\end{array}$ & $\begin{array}{l}\text { Suppressed nicotine } \\
\text { production }\end{array}$ & Zong and Wang 2004 \\
\hline & OS & $?$ & Cicer arietinum & $\begin{array}{l}\text { Induction of JA and ET } \\
\text { pathways and simultaneous } \\
\text { suppression of } \\
\text { phytohormones such as } \\
\text { gibberelic acid and auxin }\end{array}$ & Pandey et al. 2017 \\
\hline \multirow[t]{4}{*}{$\begin{array}{l}\text { Helicoverpa zea (corn } \\
\text { earworm/tomato fruitworm) }\end{array}$} & Saliva & GOX & $\begin{array}{l}\text { N. tabacum } \\
\text { Solanum } \\
\text { lycopersicum }\end{array}$ & $\begin{array}{l}\text { Suppressed induced defenses } \\
\text { and nicotine production in } \\
\text { tobacco whereas activated } \\
\text { both rapid and delayed- } \\
\text { induced defenses in tomato }\end{array}$ & $\begin{array}{l}\text { Musser et al. 2002; Tian } \\
\text { et al. } 2012\end{array}$ \\
\hline & OS & Endo-symbionts & S. lycopersicum & $\begin{array}{l}\text { Induced antiherbivore } \\
\text { defenses and triggered the } \\
\text { production of more salivary } \\
\text { elicitors (e.g., GOX) }\end{array}$ & Wang et al. 2017 \\
\hline & Frass & $?$ & $\begin{array}{l}\text { S. lycopersicum } \\
\text { leaves }\end{array}$ & $\begin{array}{l}\text { Activated herbivore defenses } \\
\text { without triggering pathogen } \\
\text { defenses }\end{array}$ & Ray et al. 2016b \\
\hline & Frass & $?$ & $\begin{array}{l}\text { S. lycopersicum } \\
\text { fruits }\end{array}$ & $\begin{array}{l}\text { Suppressed antiherbivore } \\
\text { defense genes at early time } \\
\text { points followed by an } \\
\text { activation of herbivore } \\
\text { defenses at later time points }\end{array}$ & Ray et al. 2016b \\
\hline \multirow[t]{2}{*}{$\begin{array}{l}\text { Leptinotarsa decemlineata } \\
\text { (Colorado potato beetle) }\end{array}$} & OS & Endo-symbionts & S. lycopersicum & $\begin{array}{l}\text { Induction of SA and } \\
\text { suppression of JA-induced } \\
\text { defenses (SA-JA } \\
\text { antagonism) }\end{array}$ & Chung et al. 2013 \\
\hline & & & $\begin{array}{l}\text { S. lycopersicum } \\
\text { S. melongena } \\
\text { S. dulcamara } \\
\text { S. caroliense } \\
\text { S. tuberosum } \\
\text { S. rostratum }\end{array}$ & $\begin{array}{l}\text { Host plants shapes the } \\
\text { bacterial community present } \\
\text { in the OS and aids in } \\
\text { suppression of plant } \\
\text { defenses by utilizing SA-JA } \\
\text { crosstalk }\end{array}$ & Chung et al. 2017 \\
\hline \multirow[t]{3}{*}{$\begin{array}{l}\text { Manduca sexta (tobacoo } \\
\text { hornworm) }\end{array}$} & OS & FACs & $\begin{array}{l}\text { N. attenuata } \\
\text { N. acuminata } \\
\text { N. linearis } \\
\text { N. pauciflora }\end{array}$ & $\begin{array}{l}\text { Elicited elevated levels of JA } \\
\text { and downstream of JA- } \\
\text { mediated defenses }\end{array}$ & $\begin{array}{l}\text { Kahl et al. 2000; } \\
\text { Hermsmeier et al. 2001; } \\
\text { Halitschke et al. 2003; } \\
\text { Zavala et al. 2004; } \\
\text { Wu et al. 2007; Xu et al. } \\
2015\end{array}$ \\
\hline & OS & FACs & Zea mays & Induced indirect defenses & Alborn et al. 2003 \\
\hline & OS & $?$ & S. lycopersicum & $\begin{array}{l}\text { Induction of several } \\
\text { anitnutritive defense } \\
\text { proteins }\end{array}$ & Chung and Felton 2011 \\
\hline $\begin{array}{l}\text { Mythimna loreyi (loreyi } \\
\text { leafworm) }\end{array}$ & OS & Non-FACs & Oryza sativa & $\begin{array}{l}\text { Rapid induction of early and } \\
\text { late defense responses }\end{array}$ & Shinya et al. 2016 \\
\hline $\begin{array}{l}\text { Mythimna separata (oriental } \\
\text { armyworm) }\end{array}$ & OS & $?$ & Z. mays & $\begin{array}{l}\text { Rapid reprogramming in } \\
\text { several host cell processes }\end{array}$ & $\begin{array}{l}\text { Qi et al. } 2016 \\
\text { (continued on next page) }\end{array}$ \\
\hline
\end{tabular}

\footnotetext{
${ }^{\mathrm{a}} \mathrm{GOX}=$ glucose oxidase; OS = oral secretions; $\mathrm{SA}=$ salicylic acid; JA = jasmonic acid; ET = ethylene; FACs = fatty acid-amino acid conjugates; VOCs =volatile
} organic compounds; VEG = ventral eversible gland. 
herbivory by promoting plant susceptibility. $\beta$-Glucosidase has also been identified in the OS of Pieris brassicae (Mattiacci et al.1995). Further, application of $\beta$-glucosidase on cabbage plants boosted the indirect plant defenses and is used by the predators of the attacking herbivores. Although the chemical nature of OS from both specialist (P. brassicae) and generalist (Spodoptera littoralis) insects that suppressed the plant defenses in Arabidopsis are not known, the OS contain factors that likely altered host physiology, thus leading to a better caterpillar growth (Consales et al. 2012) (Table 1). These studies suggest that chewing insects utilize a variety of HAMPs present in their OS to modulate the plant defense responses.

However, because lepidopteran caterpillars rarely regurgitated while feeding on host plants (Peiffer and Felton 2009), the regurgitant concentrations used in many of these studies should be treated with caution. A highly sensitive fluorescence dye method has been utilized to monitor and quantify the chewing insect regurgitant on host plants (Chuang et al. 2014; Chung et al. 2013; Louis et al. 2013b; Peiffer and Felton 2009). Interestingly, host plants can further influence the amount and frequency of caterpillar regurgitation. It is likely that caterpillars, depending on the host plant, secrete various concentrations of regurgitant and may help modulate plant defense responses. The caterpillars regurgitated more when they fed on the preferred hosts compared with nonpreferred host plants (Peiffer and Felton 2009). Alternatively, caterpillars, while feeding on host plants, might be regurgitating infrequently to minimize the exhibition of HAMPs or effectors to avoid escalation of plant defenses.

\section{Salivary secretions.}

Lepidopteran caterpillars secrete saliva predominantly through their labial and mandibular salivary glands (Felton et al. 2014).

Table 1. (continued from previous page)

\begin{tabular}{|c|c|c|c|c|c|}
\hline Insect & Source & Component & Host & Response & Reference \\
\hline \multirow[t]{3}{*}{$\begin{array}{l}\text { Ostrinia nubilalis (European } \\
\text { corn borer) }\end{array}$} & Saliva & GOX & Z. mays & $\begin{array}{l}\text { GOX induced both direct and } \\
\text { indirect defenses in tomato } \\
\text { whereas failed to induce } \\
\text { defenses in maize }\end{array}$ & Louis et al. 2013a and b \\
\hline & OS & Auxin & S. lycopersicum & $\begin{array}{l}\text { Promoted plant susceptibility } \\
\text { by enhancing nutritional } \\
\text { content }\end{array}$ & Dafoe et al. 2013 \\
\hline & Frass & $?$ & Z. mays & $\begin{array}{l}\text { Activated JA-related defenses } \\
\text { while suppressing SA- } \\
\text { related defenses }\end{array}$ & Ray et al. 2016b \\
\hline \multirow[t]{7}{*}{$\begin{array}{l}\text { Spodoptera exigua (beet } \\
\text { armyworm) }\end{array}$} & OS & GOX & N. attenuata & $\begin{array}{l}\text { Elicited higher } \mathrm{H}_{2} \mathrm{O}_{2} \text { and SA } \\
\text { accumulation and } \\
\text { suppressed JA- and ET- } \\
\text { dependent defenses }\end{array}$ & Diezel et al. 2009 \\
\hline & OS & FACs & Z. mays & Elicits VOCs & Alborn et al. 1997 \\
\hline & Saliva & GOX & $\begin{array}{l}\text { Medicago } \\
\quad \text { truncatula }\end{array}$ & $\begin{array}{l}\text { Suppression of herbivore } \\
\text { defenses mediated through } \\
\text { ET pathway }\end{array}$ & $\begin{array}{l}\text { Bede et al. 2006; Paudel } \\
\text { and Bede 2015 }\end{array}$ \\
\hline & Saliva & $?$ & $\begin{array}{l}\text { Arabidopsis } \\
\text { thaliana }\end{array}$ & $\begin{array}{l}\text { Suppression of JA defenses by } \\
\text { an SA-independent } \\
\text { mechanism }\end{array}$ & $\begin{array}{l}\text { Weech et al. 2008; Lan } \\
\text { et al. } 2014\end{array}$ \\
\hline & OS & $?$ & S. dulcamara & $\begin{array}{l}\text { Induced herbivore-related } \\
\text { defense genes }\end{array}$ & Lortzing et al. 2017 \\
\hline & OS & $?$ & $\begin{array}{c}\text { Gossypium } \\
\text { hirsutum }\end{array}$ & Induction of JA and gossypol & Zebelo et al. 2017 \\
\hline & $\begin{array}{l}\text { VEG } \\
\text { secretions }\end{array}$ & $?$ & S. lycopersicum & $\begin{array}{l}\text { Induced transcript levels of } \\
\text { defense-related genes and } \\
\text { indirect defenses }\end{array}$ & Zebelo et al. 2014 \\
\hline \multirow{4}{*}{$\begin{array}{l}\text { Spodoptera frugiperda (fall } \\
\text { armyworm) }\end{array}$} & Saliva & $?$ & Z. mays & Activated JA-related defenses & Chuang et al. 2014 \\
\hline & OS & Endo-symbionts & $\begin{array}{l}\text { Z. mays } \\
\text { S. lycopsersicum }\end{array}$ & $\begin{array}{l}\text { Induced defenses in host } \\
\text { plants, enhanced caterpillar } \\
\text { growth on tomato whereas } \\
\text { curtailed their growth on } \\
\text { maize plants }\end{array}$ & Acevedo et al. $2017 \mathrm{a}$ \\
\hline & Frass & Chitinases & Z. mays & $\begin{array}{l}\text { Suppressed herbivore- } \\
\text { induced plant defenses }\end{array}$ & Ray et al. $2015,2016 a$ \\
\hline & Frass & $?$ & Oryza sativa & $\begin{array}{l}\text { Induced antiherbivore } \\
\text { defenses while suppression } \\
\text { of pathogen defenses }\end{array}$ & Ray et al. $2016 b$ \\
\hline \multirow{3}{*}{$\begin{array}{l}\text { Spodoptera littoralis } \\
\quad \text { (Egyptian cotton leafworm) }\end{array}$} & OS & Non-FACs & N. miersii & Induction of JA responses & Xu et al. 2015 \\
\hline & OS & $?$ & A. thaliana & $\begin{array}{l}\text { Suppressed wound-inducible } \\
\text { plant defenses by } \\
\text { suppressing ERF/AP2 } \\
\text { transcription factor and } \\
\text { Protease Inhibitor (PI) } \\
\text { independent of JA and SA } \\
\text { pathways }\end{array}$ & Consales et al. 2012 \\
\hline & $\begin{array}{l}\text { VEG } \\
\text { secretions }\end{array}$ & $?$ & A. thaliana & $\begin{array}{l}\text { Induced early signaling } \\
\text { events }\end{array}$ & Zebelo and Maffei 2012 \\
\hline \multirow[t]{2}{*}{$\begin{array}{l}\text { Spodoptera litura (oriental } \\
\text { leafworm) }\end{array}$} & Saliva & $?$ & N. tabacum & $\begin{array}{l}\text { Induction of nicotine } \\
\text { production }\end{array}$ & Zong and Wang 2004 \\
\hline & OS & $\begin{array}{l}\text { FACs + additional } \\
\text { elicitors (?) }\end{array}$ & Glycine $\max$ & $\begin{array}{l}\text { Activation of isoflavanoid } \\
\text { biosynthesis }\end{array}$ & Nakata et al. 2016 \\
\hline
\end{tabular}


Although salivary cues have been identified in both labial and mandibular gland secretions, the majority of insect elicitors or effectors identified in the caterpillar saliva are originated from the labial glands. For example, glucose oxidase (GOX) identified in the saliva of Helicoverpa zea (corn earworm) predominantly arises from labial salivary glands, albeit lower GOX activity also was detected in the mandibular gland secretions (Eichenseer et al. 1999; Musser et al. 2002). Despite the presence of proteins identified in the caterpillar mandibular-gland extracts, their effect in altering host defenses are unknown (Eichenseer et al. 1999; Roda et al. 2004). This is, in part, because mandibular secretions may be mixed and released through OS and the other chemicals or factors present in the OS might be hampering its display in modulating plant defenses.

In addition to $H$. zea, several studies have reported GOX activity in the labial gland secretions of other caterpillars (Chuang et al. 2014; Eichenseer et al. 2010; Louis et al. 2013b) (Table 1). The GOX present in the H. zea saliva suppressed defenses and wound-induced accumulation of nicotine in Nicotiana tabacum (tobacco) (Musser et al. 2002). Quite to the contrary, GOX present in the saliva of $H$. zea and Ostrinia nubilalis induced the defense responses in tomato (Solanum lycopersicum) (Louis et al. 2013b; Tian et al. 2012). GOX is an enzyme that oxidizes glucose to gluconic acid and hydrogen peroxide $\left(\mathrm{H}_{2} \mathrm{O}_{2}\right)$, and the resultant $\mathrm{H}_{2} \mathrm{O}_{2}$ is a well-known signaling molecule that is involved in modulating plant defense responses to biotic stress (Dietz et al. 2016). The labial-gland salivary secretions are released through a structure known as a spinneret, and several studies have shown that cauterizing or ablating the spinneret dramatically reduced the deposition of saliva onto the host plants, thereby attenuating the impact of caterpillar saliva on modulating plant defenses (Louis et al. 2013b; Musser et al. 2002). Cauterizing or ablating the spinneret using a heated probe prevents salivation; however, caterpillars with ablated spinneret feed normally on the host plants (Musser et al. 2002, 2006). Thus, this technique has been extensively utilized to compare plant responses to caterpillar feeding with and without saliva (Bede et al. 2006; Lan et al. 2014; Louis et al. 2013b; Musser et al. 2002, 2006; Paudel et al. 2013; Weech et al. 2008), determining the contribution of one or more salivary effectors in modulating plant defenses.

ATP hydrolyzing enzymes, such as apyrase, ATPase, and ATP synthase, have also been identified in the saliva of $H$. zea (Wu et al. 2012). In addition to the suppression of chemical defenses, ATPases suppressed the wound-induced expression of physical defenses, such as trichomes, in tomato (Wu et al. 2012). These ATPases act as salivary effectors by hydrolyzing extracellular ATP (eATP) and potentially acting as a secondary messenger in a manner similar to $\mathrm{H}_{2} \mathrm{O}_{2}$, as mentioned above. However, it is unknown how widespread is the presence of ATPases in other caterpillars and whether ATPases present in H. zea saliva can suppress defenses in other host plants. In fact, an eATP receptor has been recently identified in Arabidopsis (Choi et al. 2014). However, it is not yet known how these salivary effectors are recognized by the host receptors. Furthermore, understanding the downstream signaling mechanisms that contribute to the eATP-induced defense signaling will eventually lead to the development of novel pest management strategies.

A recent salivary proteomic analysis of two strains of FAW ("corn strain" and "rice strain") fed on different host plants identified several categories of proteins, including salivary proteins, potentially involved in modulating plant defenses (Acevedo et al. 2017b). However, it still needs to be elucidated whether the differences in salivary proteomes are due to the original difference in the FAW strains or due to differences in the diets. Indeed, GOX and apyrases that were identified in the $H$. zea saliva and involved in plant defense regulation (Tian et al. 2012) were also detected in the salivary proteome of FAW. Several proteins were differentially identified between the saliva of FAW strains, thus indicating that host plants can further influence the plasticity of salivary composition. Similarly, varied levels of GOX production has been corroborated in many studies that involve caterpillar feeding on different host plants with diverse levels of nutritional quality (Afshar et al. 2010, 2013; Peiffer and Felton 2005; Yang et al. 2017; Zong and Wang 2004). Carbohydrates and protein concentrations in the diet act as positive regulators of GOX activity in caterpillars (Babic et al. 2008). However, carbohydrates and proteins or amino acids play a distinct role in GOX activity. It was shown that carbohydrates affect GOX transcription, while proteins present in the diet affect the translational or posttranslational regulation of GOX (Afshar et al. 2010). Another study showed that the weak induction of defenses in maize compared with tomato might be due to the lower amounts of GOX substrate (glucose) (Louis et al. 2013b), suggesting that the nutritional quality of host plants play a key role in defense modulation by GOX. Further studies are required to elucidate the role of novel HAMPs/effectors in caterpillar saliva and how they are influenced by the nutritional quality of host plants.

\section{VEG secretions.}

Besides salivary gland secretions, VEGs also release elicitors in modulating plant defenses. VEGs are located adjacent to the mandibles of lepidopterans and are known sources of HAMPs. Recent studies have indicated that secretions from VEGs induce both direct and indirect defenses in host plants (Zebelo and Maffei 2012; Zebelo et al. 2014). VEG secretions released during Spodoptera littoralis feeding on Arabidopsis triggered early signaling events, such as changes in $\mathrm{V}_{\mathrm{m}}$, and significantly elevated both cytosolic calcium levels and $\mathrm{H}_{2} \mathrm{O}_{2}$ accumulation (Zebelo and Maffei 2012). In contrast, VEG ablation of Spodoptera littoralis failed to induce the early signaling events, thus suggesting that VEG secretions are perceived by plants and are likely triggering the downstream signaling responses. Similarly, Spodoptera exigua VEG secretions induced the expression of several genes that are involved in the biosynthesis of JA and volatile organic compounds (Zebelo et al. 2014). Thus, plants that have detected secretions from VEGs mobilized both direct and indirect defense against attacking herbivore. Very recently, Dussourd et al. (2016) demonstrated that tree-feeding notodontid caterpillars, Oedemasia leptinoides, use their mandibles to girdle the stem and to subsequently bathe the girdles with fluid secretions. They further showed that the caterpillars with blocked VEGs were still able to smear the girdles with fluid, whereas caterpillars with cauterized or ablated spinneret did not, suggesting that the fluid secretions originated from the labial glands. GOX activity has been detected in the saliva of Oedemasia leptinoides (Dussourd et al. 2016); however, the exact role of saliva in modulating plant defenses is yet to be determined. Similarly, another notodontid larvae, Theroa zethus, that feeds on herbaceous members of the Euphorbiaceae, releases not only saliva but also acid secretions from VEGs at the site of feeding, presumably to suppress the plant defenses (Dussourd 2015). The question of whether VEG secretions alone or in blend with saliva are required to modulate plant defenses remains to be established.

\section{EMERGING ROLE OF INSECT ENDOSYMBIONTS AND FRASS IN REGULATING PLANT DEFENSES}

Endosymbionts in chewing herbivore secretions.

In recent years, we have witnessed a great surge in understanding the role of insect endosymbionts in altering plant defenses (Acevedo et al. 2017a; Chung et al. 2013, 2017; Wang et al. 2016a, 2017). These insect-associated endosymbionts benefit their hosts by creating physiological changes in the 
plants or through modulating the complex plant defense signaling pathways, or both. Barr et al. (2010) indicated that Diabrotica virgifera virgifera (western corn rootworm [WCR]) treated with antibiotics, to eliminate endosymbionts, induced more defense genes than untreated WCR. In contrast, a different study has disputed the role of WCR endosymbionts in modulating maize defenses (Robert et al. 2013). Either genotype differences in maize, different biotypes of WCR, or both might be accountable for the disparity between those two studies. Nevertheless, some insects will harbor a different diverse array of microbes in their gut and release them through their OS to the plant surface while they feed. Several species of gram-negative bacteria were identified in the OS of Leptinotarsa decemlineata (Colorado potato beetle [CPB]) (Chung et al. 2013). These endosymbionts present in the CPB OS are found to be involved in the activation of the SA pathway by suppressing JA-mediated defenses. As mentioned before, the SA-JA antagonism are well documented in different plant systems and insects use these defense-signaling pathways to trick the plants to acclimate for their own profit. Interestingly, a recent study has demonstrated that symbiotic bacteria present in the gut of CPB differentially suppressed plant defenses in wild and cultivated Solanum host plants and the gut bacterial communities in CPB varied drastically depending on the host plants, suggesting that plants can also alter the herbivoreassociated bacterial community (Chung et al. 2017).

Similarly, several species of symbiotic bacteria have been identified in the OS of FAW, and these herbivore-associated bacteria have the ability to mediate insect-plant interactions differently in multiple hosts (Acevedo et al. 2017a). The seven different bacterial isolates belonging to the family Enterobacteriaceae from FAW OS have been shown to differentially influence herbivore-induced defenses in tomato and maize plants (Acevedo et al. 2017a). Interestingly, it was also shown that gut-associated bacteria (Enterobacter ludwigii) in $H$. zea are required for secreting more salivary effectors (GOX) onto the insect feeding sites and for the induction of antiherbivore defense in tomato (Wang et al. 2017). However, it is not known whether the same gut-associated bacteria can aid the chewing insect to trigger the salivary effector while feeding on a different host. Taken together, these studies suggest that insect gut microbial communities are highly influenced by the host plants.

\section{Frass.}

The role of effectors present in insect frass was ignored until Ray et al. (2015) elegantly demonstrated that maize plants could perceive signals arising from caterpillar frass. In maize, caterpillar frass deposition at the site of insect feeding induced the expression of pathogen defenses while suppressing herbivore defenses. Thus, frass deposition induced SA accumulation that could potentially be involved in suppressing JA levels (Ray et al. 2015). Subsequently, it was shown that caterpillar frass utilized plant-derived chitinases PR4 and endochitinase A to, one or both, suppress plant defense and stimulate a susceptible response to enhance the performance of herbivore on the host plants (Ray et al. 2016a). However, identification of chitinases as effectors in caterpillar frass represents only the tip of the iceberg. For example, only one protein fraction among many of the fractionated frass proteins that suppressed plant defenses have thus been characterized (Ray et al. 2016a), suggesting that novel effectors from insect frass are yet to be determined. Furthermore, insect frass from various caterpillars modulated plant defenses differentially in diverse plant tissues and species (Ray et al. 2016b). It is plausible that insects utilize a particular elicitor or blend of effectors present in the insect frass to activate or suppress distinct defense responses in specific host plants. Moreover, the dynamics between insect frass and indirect plant defenses remains to be explored. It was reported that the honeydew, a digestive waste, from aphids and whiteflies can modulate plant defense responses and contains several endosymbionts (Sabri et al. 2013; Schwartzberg and Tumlinson 2014; VanDoorn et al. 2015). However, whether either the endosymbionts, herbivore-associated bacterial communities, or both are present in the chewing herbivore frass is currently unknown and needs further investigation to understand if it plays a potential role in regulating plant defenses.

In addition to insect endosymbionts and frass, oviposition by moths and butterflies trigger both direct and indirect host plant defenses and studies have shown that ovipositional fluids contain elicitors (e.g., bruchins, benzyl cyanide) that can activate defenses in host plants. Egg deposition on host plants induce several defense mechanisms (both direct and indirect), thereby preventing the eggs from hatching. Interestingly, H. zea moth oviposition on tomato was perceived as an indication for future herbivory by newly hatched larvae and activated specific defenses targeting the larvae (Kim et al. 2012). Future studies are required to elucidate what specific elicitors are present in the ovipositional fluids that specifically induce defenses against impending herbivory. For excellent reviews on HAMPs associated with egg deposition and ovipositional fluids the reader is referred to reviews by Reymond (2013) and Hilker and Fatouros $(2015,2016)$.

\section{PLANT DEFENSES TO INSECT HERBIVORE CUES}

\section{Host specificity of induced plant defenses to herbivore feeding.}

The FACs present in the OS of chewing herbivores can modulate phytohormone composition and trigger volatile production in several host plants (Schmelz et al. 2009). However, a recent study of interactions between chewing herbivores and rice has shown that FAC alone had minimal activity in eliciting defenses in rice (Shinya et al. 2016). OS from the rice specialist chewing herbivore Parnara guttata contained no measureable FACs but still were able to induce early and late defensesignaling responses. OS from Mythimna loreyi (generalist insect) contained several typical FACs; however, even after the removal of FAC from the OS, the FAC-free OS was still able to activate defenses in rice (Shinya et al. 2016). This suggests that, in rice, one or more non-FAC components may act as a critical player in modulating defenses. Furthermore, it was shown that combined actions of synthetic FAC and one or more highmolecular mass elicitor fractions from insect OS largely contributed to the activation of rice defenses. Thus, FAC amplifies the action of insect OS, leading to the activation of induced defenses in rice. Similarly, FACs present in the OS of Manduca sexta elicited distinct defense responses in six different $\mathrm{Nico}$ tiana species (Xu et al. 2015). Furthermore, different Nicotiana species exhibited extensive variation in defense responses when these plants were individually treated with OS of $M$. sexta and Spodoptera littoralis. Relative abundance of FACs present in the OS of Spodoptera littoralis was considerably less as compared with that in M. sexta (Hettenhausen et al. 2013). These findings, albeit highly speculatively, suggest that some chewing herbivores utilize FACs as a signal to amplify other herbivoreassociated elicitors to modulate plant defenses.

Similar to OS, one or more signals present in the caterpillar saliva also display host specificity. For example, GOX present in the saliva of caterpillars induced direct and indirect defenses in tomato, whereas GOX failed to activate defenses in maize (Louis et al. 2013a, 2013b; Tian et al. 2012), suggesting specificity in the role of GOX in modulating plant defenses. Further, GOX-mediated suppression of defenses in tobacco 
indicates that the nature of induction of defenses varies considerably between plants belonging to the same family (e.g., tomato and tobacco) (Musser et al. 2002; Tian et al. 2012). Interestingly, it was also shown that GOX synthesis and activity is highly host-specific; polyphagous caterpillars that have a wide host range exhibited elevated levels of GOX compared with oligophagous caterpillar species with limited host range (Eichenseer et al. 2010). Similarly, as mentioned before, in addition to the role of dietary carbohydrate and protein content, a recent comparative study demonstrated that the greater GOX activity in generalist herbivore Helicoverpa armigera was achieved through posttranscriptional regulation of GOX gene, as compared with the specialist herbivore Helicoverpa assulta (Yang et al. 2017). Specifically, the authors detected a significant correlation of higher GOX activity in generalist insects due to either greater translation efficiency, stability of GOX mRNA, or both in comparison with specialist insects (Yang et al. 2017). Based on the current understanding, it is tempting to speculate that the plantherbivore evolutionary trajectory has enabled the generalist insects to produce more salivary effectors to modulate host-specific plant defenses.

Similarly to herbivore feeding, as mentioned before, insect frass-induced plant defenses are explicit to the composition of frass and the plant tissue (e.g., leaves, fruits) on which the frass was deposited (Ray et al. 2015, 2016a and b). Table 1 summarizes the effect of host specificity of induced plant defenses to herbivore feeding.

\section{Sequence specificity of induction of plant defenses to herbivore feeding.}

Recent studies have compared the sequence-specific effects of insect feeding on systemic defenses. For example, FAW feeding on maize leaves strongly repelled subsequent belowground feeding by WCR (Huang et al. 2017). Recently, it was shown that initial feeding by FAW alters the root phenylpropanoid patterns, thereby leading to enhanced resistance to subsequent feeding by WCR (Erb et al. 2015). Interestingly, not the wounding alone but adding FAW OS to wounds triggered an avoidance response in WCR, suggesting that actual signals that induce changes in root chemistry originated from the OS of FAW. In addition, initial feeding by FAW on maize leaves caused changes in root volatiles, which also contributed to the avoidance response in WCR (Huang et al. 2017). FAW feeding on maize leaves also suppressed the root emission of the phytohormone ET, which was used by WCR to locate the suitable host plant. However, early colonization of WCR on maize roots suppressed subsequent FAW-induced root volatiles and rendered roots insensitive to above-ground feeding by FAW (Huang et al. 2017). Analysis of root volatiles that were initially infested with WCR indicated that maize roots produced elevated levels of $(E)-\beta$-caryophyllene and ET, two critical host-finding cues for WCR larvae (Robert et al. 2012). Understanding the signals arising from secretions of WCR that suppresses FAW-induced root volatiles still needs further elucidation. However, initial colonization by WCR on maize roots did not affect subsequent FAW larval performance on the maize shoots (Erb et al. 2011), suggesting that FAW can overcome defenses activated by WCR. As mentioned before, recent proteomic analysis of FAW saliva fed on different hosts has identified several effector proteins that can potentially modulate host defenses (Acevedo et al. 2017b). It is highly plausible that the recent elucidation of FAW-derived effectors and elicitors will lead to the identification of one or more novel FAW salivary components that facilitate sequence specificity of induction of host defenses. These studies suggest that one or both insect OS and saliva are likely recognized by plants and act as an important modulator in inducing or suppressing sequence specificity of induction of plant defense responses.

\section{CONCLUSIONS AND FUTURE DIRECTIONS}

The current understanding of the roles of HAMPs and effectors from chewing herbivores and its interaction with their hosts is depicted in Figure 1. Although the number of insect HAMPs and effectors known are considerably fewer compared with pathogen and microbe effectors, it is evident that identification and characterization of additional elicitors or effectors will help to design plants that can better withstand herbivore attack. Similarly to other microbes (Hewezi 2015; Lo Presti et al. 2015; Macho and Zipfel 2015), insect herbivores possibly produce a blend of herbivore-associated cues and we have just begun to identify more elicitors and effectors (e.g., insect frass and herbivore-associated endosymbionts) in modulating plant defenses. Given the diverse nature of insect herbivores, it is highly plausible that novel effectors and herbivore-associated endosymbionts are yet to be discovered. It would also be interesting to explore how these herbivore-associated cues are conserved across insect herbivores and how they are influenced by the host diet.

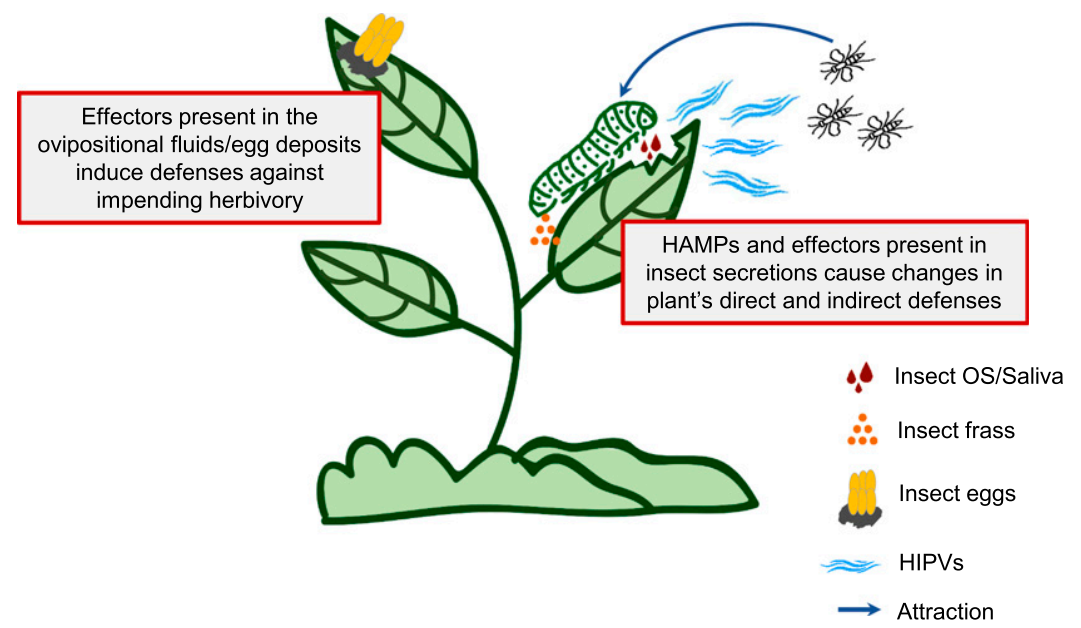

Fig. 1. Overview of plant defense responses to herbivore-associated molecular patterns (HAMPs) and effectors from chewing herbivores and their interaction with plants, insects, and predators. HIPVs = herbivore-induced plant volatiles, VOCs = volatile organic compounds, and OS = oral secretions. 
One of the most challenging questions in the study of insect HAMPs and effectors is to identify how these signals are being recognized by the host plants. Although a putative volicitin receptor in maize has been identified (Truitt et al. 2004), very little is known about HAMP receptors. This area is, in fact, relatively unexplored and future studies are required to understand the molecular and biochemical recognition of HAMPs and effectors and downstream signaling events. Concurrently, it is also very exciting that the recent advancements in "omics" technology will allow us to explore several under-studied areas in the field of plant-insect interactions. For instance, proteomics has been successfully used in identifying insect elicitors and effectors from various chewing herbivores (Acevedo et al. 2017b; Ray et al. 2016a; Tian et al. 2012). Additionally, genome-editing tools such as CRISPR-Cas9 can, potentially, be used to understand the function of insect HAMPs and effectors in modulating defenses. This approach has been elegantly used in $H$. armigera to disrupt the cadherin gene ( $\mathrm{HaCad}$ ), which was previously identified as a receptor of Bacillus thuringiensis Cry1A toxins (Wang et al. 2016b). Similarly, RNA interference-mediated gene knockdown has shown prominent results against different chewing insects (Baum et al. 2007; Bolognesi et al. 2012; $\mathrm{Hu}$ et al. 2016; Mao et al. 2007; Zhu et al. 2011). Transgenic plants that expresses double-stranded (ds)RNA or plants sprayed with dsRNA that target insect effectors could, potentially, be deployed to control insect pests. These novel approaches will help to identify additional insect HAMPs and effectors and to unravel the mechanisms of insect HAMP perception by plants and revolutionize the understanding of complex interactions between plants and insect herbivores.

\section{ACKNOWLEDGMENTS}

We thank G. W. Felton for critical reading of the manuscript. This work was supported by a National Science Foundation Nebraska EPSCoR FIRST award and start-up funds provided by University of Nebraska-Lincoln to J. Louis.

\section{LITERATURE CITED}

Acevedo, F. E., Peiffer, M., Tan, C.-W., Stanley, B. A., Stanley, A., Wang, J., Jones, A. G., Hoover, K., Rosa, C., Luthe, D., and Felton, G. 2017a. Fall armyworm-associated gut bacteria modulate plant defense responses. Mol. Plant-Microbe Interact 30:127-137.

Acevedo, F. E., Stanley, B. A., Stanley, A., Peiffer, M., Luthe, D. S., and Felton, G. W. 2017b. Quantitative proteomic analysis of the fall armyworm saliva. Insect Biochem. Mol. Biol. 86:81-92.

Afshar, K., Dube, F. F., Najafabadi, H. S., Bonneil, E., Thibault, P., Salavati, R., and Bede, J. C. 2013. Insights into the insect salivary gland proteome: diet-associated changes in caterpillar labial salivary proteins. J. Insect Physiol. 59:351-366.

Afshar, K., Dufresne, P. J., Pan, L., Merkx-Jacques, M., and Bede, J. C. 2010. Diet-specific salivary gene expression and glucose oxidase activity in Spodoptera exigua (Lepidoptera: Noctuidae) larvae. J. Insect Physiol 56:1798-1806.

Alborn, H. T., Brennan, M. M., and Tumlinson, J. H. 2003. Differential activity and degradation of plant volatile elicitors in regurgitant of tobacco hornworm (Manduca sexta) larvae. J. Chem. Ecol. 29:1357-1372.

Alborn, H. T., Hansen, T. V., Jones, T. H., Bennett, D. C., Tumlinson, J. H., Schmelz, E. A., and Teal, P. E. A. 2007. Disulfooxy fatty acids from the American bird grasshopper Schistocerca americana, elicitors of plant volatiles. Proc. Natl. Acad. Sci. U.S.A. 104:12976-12981.

Alborn, H. T., Turlings, T. C. J., Jones, T. H., Stenhagen, G., Loughrin, J. H., and Tumlinson, J. H. 1997. An elicitor of plant volatiles from beet armyworm oral secretion. Science 276:945-949.

Asai, S., and Shirasu, K. 2015. Plant cells under siege: Plant immune system versus pathogen effectors. Curr. Opin. Plant Biol. 28:1-8.

Babic, B., Poisson, A., Darwish, S., Lacasse, J., Merkx-Jacques, M., Despland, E., and Bede, J. C. 2008. Influence of dietary nutritional composition on caterpillar salivary enzyme activity. J. Insect Physiol. 54:286-296.

Barr, K. L., Hearne, L. B., Briesacher, S., Clark, T. L., and Davis, G. E. 2010. Microbial symbionts in insects influence down-regulation of defense genes in maize. PLoS One 5:e11339.
Baum, J. A., Bogaert, T., Clinton, W., Heck, G. R., Feldmann, P., Ilagan, O., Johnson, S., Plaetinck, G., Munyikwa, T., Pleau, M., Vaughn, T., and Roberts, J. 2007. Control of coleopteran insect pests through RNA interference. Nat. Biotechnol. 25:1322-1326.

Bede, J. C., Musser, R. O., Felton, G. W., and Korth, K. L. 2006. Caterpillar herbivory and salivary enzymes decrease transcript levels of Medicago truncatula genes encoding early enzymes in terpenoid biosynthesis. Plant Mol. Biol. 60:519-531.

Bolognesi, R., Ramaseshadri, P., Anderson, J., Bachman, P., Clinton, W., Flannagan, R., Ilagan, O., Lawrence, C., Levine, S., Moar, W., Mueller, G., Tan, J., Uffman, J., Wiggins, E., Heck, G., and Segers, G. 2012. Characterizing the mechanism of action of double-stranded RNA activity against western corn rootworm (Diabrotica virgifera virgifera LeConte). PLoS One 7:e47534.

Bonaventure, G. 2012. Perception of insect feeding by plants. Plant Biol Stuttg 14:872-880.

Bosch, M., Berger, S., Schaller, A., and Stintzi, A. 2014a. Jasmonatedependent induction of polyphenol oxidase activity in tomato foliage is important for defense against Spodoptera exigua but not against Manduca sexta. BMC Plant Biol. 14:257.

Bosch, M., Wright, L. P., Gershenzon, J., Wasternack, C., Hause, B., Schaller, A., and Stintzi, A. 2014b. Jasmonic acid and its precursor 12oxophytodienoic acid control different aspects of constitutive and induced herbivore defenses in tomato. Plant Physiol. 166:396-410.

Choi, J., Tanaka, K., Cao, Y., Qi, Y., Qiu, J., Liang, Y., Lee, S. Y., and Stacey, G. 2014. Identification of a plant receptor for extracellular ATP Science 343:290-294.

Chuang, W.-P., Herde, M., Ray, S., Castano-Duque, L., Howe, G. A., and Luthe, D. S. 2014. Caterpillar attack triggers accumulation of the toxic maize protein RIP2. New Phytol. 201:928-939.

Chung, S. H., and Felton, G. W. 2011. Specificity of induced resistance in tomato against specialist lepidopteran and coleopteran species. J. Chem. Ecol. 37:378-386.

Chung, S. H., Rosa, C., Scully, E. D., Peiffer, M., Tooker, J. F., Hoover, K. Luthe, D. S., and Felton, G. W. 2013. Herbivore exploits orally secreted bacteria to suppress plant defenses. Proc. Natl. Acad. Sci. U.S.A. 110: 15728-15733.

Chung, S. H., Scully, E. D., Peiffer, M., Geib, S. M., Rosa, C., Hoover, K., and Felton, G. W. 2017. Host plant species determines symbiotic bacterial community mediating suppression of plant defenses. Sci. Rep. 7:39690.

Consales, F., Schweizer, F., Erb, M., Gouhier-Darimont, C., Bodenhausen, N., Bruessow, F., Sobhy, I., and Reymond, P. 2012. Insect oral secretions suppress wound-induced responses in Arabidopsis. J. Exp. Bot. 63 727-737.

Dafoe, N. J., Thomas, J. D., Shirk, P. D., Legaspi, M. E., Vaughan, M. M., Huffaker, A., Teal, P. E., and Schmelz, E. A. 2013. European corn borer (Ostrinia nubilalis) induced responses enhance susceptibility in maize. PLoS One 8:e73394.

Dietz, K.-J., Mittler, R., and Noctor, G. 2016. Recent progress in understanding the role of reactive oxygen species in plant cell signaling. Plant Physiol. 171:1535-1539.

Diezel, C., von Dahl, C. C., Gaquerel, E., and Baldwin, I. T. 2009. Different lepidopteran elicitors account for cross-talk in herbivory-induced phytohormone signaling. Plant Physiol. 150:1576-1586.

Dussourd, D. E. 2015. Theroa zethus caterpillars use acid secretion of antipredator gland to deactivate plant defense. PLoS One 10:e0141924.

Dussourd, D. E., Peiffer, M., and Felton, G. W. 2016. Chew and spit: Treefeeding notodontid caterpillars anoint girdles with saliva. ArthropodPlant Interact. 10:143-150.

Eichenseer, H., Mathews, M. C., Bi, J. L., Murphy, J. B., and Felton, G. W. 1999. Salivary glucose oxidase: multifunctional roles for helicoverpa zea? Arch. Insect Biochem. Physiol. 42:99-109.

Eichenseer, H., Mathews, M. C., Powell, J. S., and Felton, G. W. 2010. Survey of a salivary effector in caterpillars: Glucose oxidase variation and correlation with host range. J. Chem. Ecol. 36:885-897.

Erb, M., Meldau, S., and Howe, G. A. 2012. Role of phytohormones in insect-specific plant reactions. Trends Plant Sci. 17:250-259.

Erb, M., Robert, C. A., Hibbard, B. E., and Turlings, T. C. 2011. Sequence of arrival determines plant-mediated interactions between herbivores. J. Ecol. 99:7-15.

Erb, M., Robert, C. A. M., Marti, G., Lu, J., Doyen, G. R., Villard, N., Barrière, Y., French, B. W., Wolfender, J.-L., Turlings, T. C. J., and Gershenzon, J. 2015. A physiological and behavioral mechanism for leaf herbivore-induced systemic root resistance. Plant Physiol. 169: 2884-2894.

Felton, G. W., Chung, S. H., Hernandez, M. G. E., Louis, J., Peiffer, M., and Tian, D. 2014. Herbivore oral secretions are the first line of protection 
against plant-induced defences. Pages 37-76 in: Annual Plant Reviews. Vol. 47. C. Voelckel, and G. Jander, eds. John Wiley \& Sons, Ltd. Chichester, U.K.

Felton, G. W., and Tumlinson, J. H. 2008. Plant-insect dialogs: Complex interactions at the plant-insect interface. Curr. Opin. Plant Biol. 11: 457-463.

Guo, H., Wielsch, N., Hafke, J. B., Svatoš, A., Mithöfer, A., and Boland, W. 2013. A porin-like protein from oral secretions of Spodoptera littoralis larvae induces defense-related early events in plant leaves. Insect Biochem. Mol. Biol. 43:849-858.

Guo, H. M., Li, H. C., Zhou, S. R., Xue, H. W., and Miao, X. X. 2014. Cis12-oxo-phytodienoic acid stimulates rice defense response to a piercingsucking insect. Mol. Plant 7:1683-1692.

Halitschke, R., Gase, K., Hui, D., Schmidt, D. D., and Baldwin, I. T. 2003 Molecular interactions between the specialist herbivore Manduca sexta (lepidoptera, sphingidae) and its natural host Nicotiana attenuata. VI. Microarray analysis reveals that most herbivore-specific transcriptional changes are mediated by fatty acid-amino acid conjugates. Plant Physiol 131:1894-1902.

Halitschke, R., Hamilton, J. G., and Kessler, A. 2011. Herbivore-specific elicitation of photosynthesis by mirid bug salivary secretions in the wild tobacco Nicotiana attenuata. New Phytol. 191:528-535.

Heil, M., Ibarra-Laclette, E., Adame-Álvarez, R. M., Martínez, O., Ramirez-Chávez, E., Molina-Torres, J., and Herrera-Estrella, L. 2012. How plants sense wounds: Damaged-self recognition is based on plantderived elicitors and induces octadecanoid signaling. PLoS One 7:e30537.

Hermsmeier, D., Schittko, U., and Baldwin, I. T. 2001. Molecular interactions between the specialist herbivore Manduca sexta (Lepidoptera, Sphingidae) and its natural host Nicotiana attenuata. I. Large-scale changes in the accumulation of growth- and defense-related plant mRNAs. Plant Physiol. 125:683-700.

Hettenhausen, C., Baldwin, I. T., and Wu, J. 2013. Nicotiana attenuata MPK4 suppresses a novel jasmonic acid (JA) signaling-independent defense pathway against the specialist insect Manduca sexta, but is no required for the resistance to the generalist Spodoptera littoralis. New Phytol. 199:787-799.

Hewezi, T. 2015. Cellular signaling pathways and posttranslational modifications mediated by nematode effector proteins. Plant Physiol. 169:1018-1026.

Hilker, M., and Fatouros, N. E. 2015. Plant responses to insect egg deposition. Annu. Rev. Entomol. 60:493-515.

Hilker, M., and Fatouros, N. E. 2016. Resisting the onset of herbivore attack: Plants perceive and respond to insect eggs. Curr. Opin. Plant Biol. 32:9-16.

Howe, G. A., and Jander, G. 2008. Plant immunity to insect herbivores. Annu. Rev. Plant Biol. 59:41-66.

Hu, X., Richtman, N. M., Zhao, J.-Z., Duncan, K. E., Niu, X., Procyk, L. A., Oneal, M. A., Kernodle, B. M., Steimel, J. P., Crane, V. C., Sandahl, G., Ritland, J. L., Howard, R. J., Presnail, J. K., Lu, A. L., and Wu, G. 2016. Discovery of midgut genes for the RNA interference control of corn rootworm. Sci. Rep. 6:30542.

Huang, W., Robert, C. A. M., Hervé, M. R., Hu, L., Bont, Z., and Erb, M. 2017. A mechanism for sequence specificity in plant-mediated interactions between herbivores. New Phytol. 214:169-179.

Huffaker, A., Pearce, G., Veyrat, N., Erb, M., Turlings, T. C. J., Sartor, R., Shen, Z., Briggs, S. P., Vaughan, M. M., Alborn, H. T., Teal, P. E. A., and Schmelz, E. A. 2013. Plant elicitor peptides are conserved signals regulating direct and indirect antiherbivore defense. Proc. Natl. Acad. Sci. U.S.A. 110:5707-5712.

Kahl, J., Siemens, D. H., Aerts, R. J., Gäbler, R., Kühnemann, F., Preston, C. A., and Baldwin, I. T. 2000. Herbivore-induced ethylene suppresses a direct defense but not a putative indirect defense against an adapted herbivore. Planta 210:336-342.

Kaloshian, I., and Walling, L. L. 2016. Hemipteran and dipteran pests: Effectors and plant host immune regulators. J. Integr. Plant Biol. 58:350-361.

Kessler, A., and Baldwin, I. T. 2001. Defensive function of herbivoreinduced plant volatile emissions in nature. Science 291:2141-2144.

Kim, J., Tooker, J. F., Luthe, D. S., De Moraes, C. M., and Felton, G. W. 2012. Insect eggs can enhance wound response in plants: A study system of tomato Solanum lycopersicum L. and Helicoverpa zea Boddie. PLoS One 7:e37420.

Koornneef, A., and Pieterse, C. M. 2008. Cross talk in defense signaling. Plant Physiol. 146:839-844.

Korpita, T., Gómez, S., and Orians, C. M. 2014. Cues from a specialist herbivore increase tolerance to defoliation in tomato. Funct. Ecol. 28:395-401.

Lan, Z., Krosse, S., Achard, P., van Dam, N. M., and Bede, J. C. 2014. DELLA proteins modulate Arabidopsis defences induced in response to caterpillar herbivory. J. Exp. Bot. 65:571-583.
Lo Presti, L., Lanver, D., Schweizer, G., Tanaka, S., Liang, L., Tollot, M., Zuccaro, A., Reissmann, S., and Kahmann, R. 2015. Fungal effectors and plant susceptibility. Annu. Rev. Plant Biol. 66:513-545.

López-Galiano, M. J., Ruiz-Arroyo, V. M., Fernández-Crespo, E., Rausell, C., Real, M. D., García-Agustín, P., González-Bosch, C., and GarcíaRobles, I. 2017. Oxylipin mediated stress response of a miraculin-like protease inhibitor in Hexanoic acid primed eggplant plants infested by Colorado potato beetle. J. Plant Physiol. 215:59-64.

Lortzing, T., Firtzlaff, V., Nguyen, D., Rieu, I., Stelzer, S., Schad, M., Kallarackal, J., and Steppuhn, A. 2017. Transcriptomic responses of Solanum dulcamara to natural and simulated herbivory. Mol. Ecol. Resour. Published online. 10.1111/1755-0998.12687

Louis, J., Luthe, D. S., and Felton, G. W. 2013a. Salivary signals of European corn borer induce indirect defenses in tomato. Plant Signal Behav. 8:e27318.

Louis, J., Peiffer, M., Ray, S., Luthe, D. S., and Felton, G. W. 2013b. Hostspecific salivary elicitor(s) of European corn borer induce defenses in tomato and maize. New Phytol. 199:66-73.

Macho, A. P., and Zipfel, C. 2015. Targeting of plant pattern recognition receptor-triggered immunity by bacterial type-III secretion system effectors. Curr. Opin. Microbiol. 23:14-22

Mao, Y.-B., Cai, W.-J., Wang, J.-W., Hong, G.-J., Tao, X.-Y., Wang, L.-J., Huang, Y.-P., and Chen, X.-Y. 2007. Silencing a cotton bollworm P450 monooxygenase gene by plant-mediated RNAi impairs larval tolerance of gossypol. Nat. Biotechnol. 25:1307-1313.

Mattiacci, L., Dicke, M., and Posthumus, M. A. 1995. beta-Glucosidase: An elicitor of herbivore-induced plant odor that attracts host-searching parasitic wasps. Proc. Natl. Acad. Sci. U.S.A. 92:2036-2040.

Meza-Canales, I. D., Meldau, S., Zavala, J. A., and Baldwin, I. T. 2017 Herbivore perception decreases photosynthetic carbon assimilation and reduces stomatal conductance by engaging 12-oxo-phytodienoic acid, mitogen-activated protein kinase 4 and cytokinin perception. Plant Cell Environ. 40:1039-1056.

Mithöfer, A., and Boland, W. 2008. Recognition of herbivory-associated molecular patterns. Plant Physiol. 146:825-831.

Musser, R. O., Farmer, E., Peiffer, M., Williams, S. A., and Felton, G. W. 2006. Ablation of caterpillar labial salivary glands: Technique for determining the role of saliva in insect-plant interactions. J. Chem. Ecol. 32:981-992

Musser, R. O., Hum-Musser, S. M., Eichenseer, H., Peiffer, M., Ervin, G., Murphy, J. B., and Felton, G. W. 2002. Herbivory: Caterpillar saliva beats plant defences. Nature 416:599-600.

Nakata, R., Kimura, Y., Aoki, K., Yoshinaga, N., Teraishi, M., Okumoto, Y., Huffaker, A., Schmelz, E. A., and Mori, N. 2016. Inducible de novo biosynthesis of isoflavonoids in soybean leaves by Spodoptera litura derived elicitors: Tracer techniques aided by high resolution LCMS. J. Chem. Ecol. 42:1226-1236.

Pandey, S. P., Srivastava, S., Goel, R., Lakhwani, D., Singh, P., Asif, M. H., and Sane, A. P. 2017. Simulated herbivory in chickpea causes rapid changes in defense pathways and hormonal transcription networks of JA/ethylene/GA/auxin within minutes of wounding. Sci. Rep. 7:44729.

Park, S. W., Li, W., Viehhauser, A., He, B., Kim, S., Nilsson, A. K Andersson, M. X., Kittle, J. D., Ambavaram, M. M., Luan, S., Esker, A. R. Tholl, D., Cimini, D., Ellerström, M., Coaker, G., Mitchell, T. K., Pereira, A., Dietz, K.-J., and Lawrence, C. B. 2013. Cyclophilin 20-3 relays a 12oxo-phytodienoic acid signal during stress responsive regulation of cellular redox homeostasis. Proc. Natl. Acad. Sci. U.S.A. 110:9559-9564.

Paudel, J., Copley, T., Amirizian, A., Prado, A., and Bede, J. C. 2013. Arabidopsis redox status in response to caterpillar herbivory. Front. Plant Sci. 4:113.

Paudel, J. R., and Bede, J. C. 2015. Ethylene signaling modulates herbivoreinduced defense responses in the model legume Medicago truncatula. Mol. Plant-Microbe Interact 28:569-579

Peiffer, M., and Felton, G. W. 2005. The host plant as a factor in the synthesis and secretion of salivary glucose oxidase in larval Helicoverpa zea. Arch. Insect Biochem. Physiol. 58:106-113.

Peiffer, M., and Felton, G. W. 2009. Do caterpillars secrete "oral secretions"? J. Chem. Ecol. 35:326-335

Qi, J., Sun, G., Wang, L., Zhao, C., Hettenhausen, C., Schuman, M. C., Baldwin, I. T., Li, J., Song, J., Liu, Z., Xu, G., Lu, X., and Wu, J. 2016. Oral secretions from Mythimna separata insects specifically induce defence responses in maize as revealed by high-dimensional biological data. Plant Cell Environ. 39:1749-1766.

Rao, S. A. K., Carolan, J. C., and Wilkinson, T. L. 2016. Proteomic insights into the hidden world of phloem sap feeding. Pages 49-61 in Management of Insect Pests to Agriculture. Czosnek, H., and Ghanim, M., eds. Springer International Publishing, Cham, Switzerland.

Ray, S., Alves, P. C. M. S., Ahmad, I., Gaffoor, I., Acevedo, F. E., Peiffer, M., Jin, S., Han, Y., Shakeel, S., Felton, G. W., and Luthe, D. S. 2016a 
Turnabout is fair play: Herbivory-induced plant chitinases excreted in fall armyworm frass suppress herbivore defenses in maize. Plant Physiol. 171:694-706.

Ray, S., Basu, S., Rivera-Vega, L. J., Acevedo, F. E., Louis, J., Felton, G. W., and Luthe, D. S. 2016b. Lessons from the far end: Caterpillar FRASS-induced defenses in maize, rice, cabbage, and tomato. J. Chem. Ecol. 42:1130-1141.

Ray, S., Gaffor, I., Acevedo, F. E., Helms, A., Chuang, W.-P., Tooker, J., Felton, G. W., and Luthe, D. S. 2015. Maize plants recognize herbivoreassociated cues from caterpillar frass. J. Chem. Ecol. 41:781-792.

Reymond, P. 2013. Perception, signaling and molecular basis of oviposition-mediated plant responses. Planta 238:247-258.

Robert, C. A. M., Erb, M., Duployer, M., Zwahlen, C., Doyen, G. R., and Turlings, T. C. J. 2012. Herbivore-induced plant volatiles mediate host selection by a root herbivore. New Phytol. 194:1061-1069.

Robert, C. A. M., Ferrieri, R. A., Schirmer, S., Babst, B. A., Schueller, M. J., Machado, R. A. R., Arce, C. C. M., Hibbard, B. E., Gershenzon, J., Turlings, T. C. J., and Erb, M. 2014. Induced carbon reallocation and compensatory growth as root herbivore tolerance mechanisms. Plant Cell Environ. 37:2613-2622.

Robert, C. A. M., Frank, D. L., Leach, K. A., Turlings, T. C. J., Hibbard, B. E., and Erb, M. 2013. Direct and indirect plant defenses are not suppressed by endosymbionts of a specialist root herbivore. J. Chem. Ecol. 39:507-515.

Roda, A., Halitschke, R., Steppuhn, A., and Baldwin, I. T. 2004. Individual variability in herbivore-specific elicitors from the plant's perspective. Mol. Ecol. 13:2421-2433.

Sabri, A., Vandermoten, S., Leroy, P. D., Haubruge, E., Hance, T., Thonart, P., De Pauw, E., and Francis, F. 2013. Proteomic investigation of aphid honeydew reveals an unexpected diversity of proteins. PLoS One 8:e74656.

Schäfer, M., Fischer, C., Meldau, S., Seebald, E., Oelmüller, R., and Baldwin, I. T. 2011. Lipase activity in insect oral secretions mediates defense responses in Arabidopsis. Plant Physiol. 156:1520-1534.

Schäfer, M., Meza-Canales, I. D., Navarro-Quezada, A., Brütting, C., Vanková, R., Baldwin, I. T., and Meldau, S. 2015. Cytokinin levels and signaling respond to wounding and the perception of herbivore elicitors in Nicotiana attenuata. J. Integr. Plant Biol. 57:198-212.

Schmelz, E. A., Engelberth, J., Alborn, H. T., Tumlinson, J. H., 3rd, and Teal, P. E. A. 2009. Phytohormone-based activity mapping of insect herbivore-produced elicitors. Proc. Natl. Acad. Sci. U.S.A. 106:653-657.

Schmelz, E. A., LeClere, S., Carroll, M. J., Alborn, H. T., and Teal, P. E. A. 2007. Cowpea chloroplastic ATP synthase is the source of multiple plant defense elicitors during insect herbivory. Plant Physiol. 144:793-805.

Schwartzberg, E. G., and Tumlinson, J. H. 2014. Aphid honeydew alters plant defence responses. Funct. Ecol. 28:386-394.

Shinya, T., Hojo, Y., Desaki, Y., Christeller, J. T., Okada, K., Shibuya, N., and Galis, I. 2016. Modulation of plant defense responses to herbivores by simultaneous recognition of different herbivore-associated elicitors in rice. Sci. Rep. 6:32537.

Stintzi, A., Weber, H., Reymond, P., Browse, J., and Farmer, E. E. 2001. Plant defense in the absence of jasmonic acid: The role of cyclopentenones. Proc. Natl. Acad. Sci. U.S.A. 98:12837-12842.

Taki, N., Sasaki-Sekimoto, Y., Obayashi, T., Kikuta, A., Kobayashi, K., Ainai, T., Yagi, K., Sakurai, N., Suzuki, H., Masuda, T., Takamiya, K., Shibata, D., Kobayashi, Y., and Ohta, H. 2005. 12-oxo-phytodienoic acid triggers expression of a distinct set of genes and plays a role in woundinduced gene expression in Arabidopsis. Plant Physiol. 139:1268-1283.

Thaler, J. S., Humphrey, P. T., and Whiteman, N. K. 2012. Evolution of jasmonate and salicylate signal crosstalk. Trends Plant Sci. 17:260-270.

Tian, D., Peiffer, M., Shoemaker, E., Tooker, J., Haubruge, E., Francis, F., Luthe, D. S., and Felton, G. W. 2012. Salivary glucose oxidase from caterpillars mediates the induction of rapid and delayed-induced defenses in the tomato plant. PLoS One 7:e36168.

Truitt, C. L., Wei, H.-X., and Paré, P. W. 2004. A plasma membrane protein from Zea mays binds with the herbivore elicitor volicitin. Plant Cell 16:523-532.

Turlings, T. C. J., McCall, P. J., Alborn, H. T., and Tumlinson, J. H. 1993. An elicitor in caterpillar oral secretions that induces corn seedlings to emit chemical signals attractive to parasitic wasps. J. Chem. Ecol. 19:411-425.

Turlings, T. C. J., Tumlinson, J. H., and Lewis, W. J. 1990. Exploitation of herbivore-induced plant odors by host-seeking parasitic wasps. Science 250:1251-1253.

van Bel, A. J., and Will, T. 2016. Functional evaluation of proteins in watery and gel saliva of aphids. Front. Plant Sci. 7:1840.

VanDoorn, A., de Vries, M., Kant, M. R., and Schuurink, R. C. 2015. Whiteflies glycosylate salicylic acid and secrete the conjugate via their honeydew. J. Chem. Ecol. 41:52-58.

Wang, J., Chung, S. H., Peiffer, M., Rosa, C., Hoover, K., Zeng, R., and Felton, G. W. 2016a. Herbivore oral secreted bacteria trigger distinct defense responses in preferred and non-preferred host plants. J. Chem. Ecol. 42:463-474.

Wang, J., Peiffer, M., Hoover, K., Rosa, C., Zeng, R., and Felton, G. W. 2017. Helicoverpa zea gut-associated bacteria indirectly induce defenses in tomato by triggering a salivary elicitor(s). New Phytol. 214:1294-1306.

Wang, J., Zhang, H., Wang, H., Zhao, S., Zuo, Y., Yang, Y., and Wu, Y. 2016b. Functional validation of cadherin as a receptor of $\mathrm{Bt}$ toxin Cry1Ac in Helicoverpa armigera utilizing the CRISPR/Cas9 system. Insect Biochem. Mol. Biol. 76:11-17.

Weech, M. H., Chapleau, M., Pan, L., Ide, C., and Bede, J. C. 2008. Caterpillar saliva interferes with induced Arabidopsis thaliana defence responses via the systemic acquired resistance pathway. J. Exp. Bot. 59: 2437-2448.

Wu, J., Hettenhausen, C., Meldau, S., and Baldwin, I. T. 2007. Herbivory rapidly activates MAPK signaling in attacked and unattacked leaf regions but not between leaves of Nicotiana attenuata. Plant Cell 19:1096-1122.

Wu, S., Peiffer, M., Luthe, D. S., and Felton, G. W. 2012. ATP hydrolyzing salivary enzymes of caterpillars suppress plant defenses. PLoS One 7:e41947.

$\mathrm{Xu}$, S., Zhou, W., Pottinger, S., and Baldwin, I. T. 2015. Herbivore associated elicitor-induced defences are highly specific among closely related Nicotiana species. BMC Plant Biol. 15:2.

Yang, L., Wang, X., Bai, S., Li, X., Gu, S., Wang, C.-Z., and Li, X. 2017. Expressional divergence of insect GOX genes: From specialist to generalist glucose oxidase. J. Insect Physiol. 100:21-27.

Zavala, J. A., Patankar, A. G., Gase, K., Hui, D., and Baldwin, I. T. 2004 Manipulation of endogenous trypsin proteinase inhibitor production in Nicotiana attenuata demonstrates their function as antiherbivore defenses. Plant Physiol. 134:1181-1190.

Zebelo, S., Disi, J., Balusu, R., Reeves, B., and Fadamiro, H. 2017. Spodoptera exigua modulates gossypol biosynthesis in cotton Gossypium hirsutum. J. Plant Interact. 12:121-127.

Zebelo, S., Piorkowski, J., Disi, J., and Fadamiro, H. 2014. Secretions from the ventral eversible gland of Spodoptera exigua caterpillars activate defense-related genes and induce emission of volatile organic compounds in tomato, Solanum lycopersicum. BMC Plant Biol. 14:140.

Zebelo, S. A., and Maffei, M. E. 2012. The ventral eversible gland (VEG) of Spodoptera littoralis triggers early responses to herbivory in Arabidopsis thaliana. Arthropod-Plant Interact. 6:543-551.

Zhu, F., Xu, J., Palli, R., Ferguson, J., and Palli, S. R. 2011. Ingested RNA interference for managing the populations of the Colorado potato beetle, Leptinotarsa decemlineata. Pest Manag. Sci. 67:175-182.

Zong, N., and Wang, C. 2004. Induction of nicotine in tobacco by herbivory and its relation to glucose oxidase activity in the labial gland of three noctuid caterpillars. Chin. Sci. Bull. 49:1596-1601. 